\title{
Halina ŚWIĘCZKOWSKA
}

\section{CZY MYŚLIMY ALGORYTMEM?}

Tytuł artykułu sugerować może, że dokonam tu rozstrzygnięć dotyczących istoty działania mechanizmów poznawczych, dostarczając argumentów na rzecz tezy o algorytmiczności procesów myślowych lub tezę tę obalających. Problem w tym, że radykalne rozstrzygnięcia są na obecnym etapie badań nad funkcjami poznawczymi mózgu/umysłu niemożliwe, a uczeni badający ten problem formułują różne, często wykluczające się hipotezy i teorie. Owe hipotezy czy teorie odwołują się przede wszystkim do materiału empirycznego, ale gromadzone fakty stanowią elementy pewnego modelu, którego kształt w zasadniczym stopniu zależy od przyjętych założeń filozoficznych.

Tak właśnie jest, między innymi, w przypadku hipotezy funkcjonowania umysłu przedstawionej przez amerykańskiego neurologa Antonio Damasio, która zakłada ścisłą współzależność pomiędzy ciałem a umysłem, a jej filozoficzny fundament stanowi negacja kartezjańskiego dualizmu. W wydanej ostatnio książce Błąd Kartezjusza, Damasio prowadzi polemikę z podstawowymi założeniami tej odmiany racjonalizmu, którą przesiąknięta jest myśl Zachodu (Damasio 1999).

Damasio pisze, że umysł zdaje się opierać na określonych systemach mózgowych, a zatem muszą istnieć zarówno funkcjonalne, jak i anatomiczne powiązania pomiędzy umysłem, uczuciami oraz ciałem. Wygląda na to, że pochłania nas pasja rozumowania, popęd, który rodzi się $\mathrm{w}$ jądrze mózgu, przenika inne elementy układu nerwowego i ujawnia się w postaci uczuć lub nie uświadamianych mechanizmów ukierunkowujących podejmowanie decyzji. Umysł - od umysłu praktycznego do teoretycznego - prawdopodobnie opiera się na zawładnięciu owym wrodzonym popędem. Gdy popęd ten zniknie, nie osiagnniesz nigdy mistrzostwa. Lecz samo posiadanie go nie czyni cię mistrzem.

Damasio koncentruje się przede wszystkim na emocjach, kwestionując dogmat sprzeczności między emocjami a racjonalnym podejmowaniem decyzji i 
określa właściwą rolę uczuć w działaniach człowieka, ale analizuje także tę część procesów myślowych, którą nazywamy rozumowaniem. Celem rozumowania jest podejmowanie decyzji, a istotę podejmowanych decyzji stanowi dokonywanie wyborów reakcji: działań niewerbalnych, słów, zdań czy jakiejś kombinacji tych elementów, należącej do całego zbioru reakcji w danej chwili. Rozumowanie i decydowanie wymagają posiadania przez decydującego wiedzy a) o sytuacji, która wymaga podjęcia decyzji, b) o różnych możliwościach działania (reakcji) oraz o konsekwencjach wyboru każdej z dostępnych opcji w odniesieniu do bliższej i dalszej przyszłości. Rozumowanie i decydowanie wymaga zatem posiadania przez jednostkę pewnej strategii, opartej na regułach logiki (Damasio 1999, 191 i n.).

Damasio dyskutuje model podejmowania procesów decyzyjnych oparty na tradycyjnym fundamencie rozumowym. Racjonalnego rozumowania nie mogą zakłócać namiętności. Zgodnie z tym podejściem człowiek gromadzi różne scenariusze rozwoju wypadków i wykorzystuje odpowiednio bieżące strategie, dokonując analizy zysków i strat. Biorąc pod uwagę subiektywnie pojmowaną użyteczność, którą pragnie zmaksymalizować, wnioskuje logicznie, co jest dla niego dobre lub złe. Znaczna część tych obliczeń opiera się na tworzeniu kolejnych możliwych scenariuszy rozwoju wypadków, opartych m. in. na obrazach wizualnych i słuchowych, jak i na tworzeniu towarzyszącej im narracji werbalnej, niezbędnej do utrzymania procesu logicznego rozumowania. Damasio twierdzi, że gdyby ta strategia była jedyną, racjonalność $\mathrm{w}$ tym rozumieniu nie mogłaby istnieć. $\mathrm{W}$ najlepszym razie proces podejmowania decyzji zajmowałby nadzwyczaj dużo czasu. Na przeszkodzie efektywności tego modelu staje również ograniczoność uwagi i pamięci, a także, jak sugeruje, niedoskonałość naszych strategii rozumowania, nasza niewiedza czy błędne wykorzystywanie teorii prawdopodobieństwa oraz statystyki. Ale, jak zauważa Damasio, nasz mózg często potrafi podejmować właściwe decyzje w ciagu sekund czy minut, zależnie od tego, jaki czas uznany zostanie za odpowiedni w odniesieniu do celu, który chcemy osiagnąć. Jeśli jest to możliwe, musi on dokonywać cudów nie ograniczających się do stosowania „czystego rozumu”. Potrzebny jest zatem alternatywny model jego funkcjonowania (Damasio 1999, 198 i n.).

Alternatywą dla czystego rozumu staje się hipoteza „markera somatycznego". Zdaniem Damasio, markery somatyczne to specjalne rodzaje 
uczuć generowanych na podstawie wtórnych emocji (Damasio 1999, 200). Te emocje $\mathrm{i}$ uczucia zostały połączone $\mathrm{w}$ procesie uczenia się $\mathrm{z}$ przewidywalnymi przyszłymi skutkami pewnych scenariuszy rozwoju wypadków. Markery somatyczne nie wyręczaja nas $w$ rozumowaniu. Towarzyszą rozważaniom poprzez uwypuklanie niektórych opcji (szczególnie niebezpiecznych lub korzystnych) i szybkie eliminowanie ich z dalszego toku analizy. Można je sobie wyobrażać jako system automatycznego przewidywania i selekcji, który działa, czy tego chcemy, czy nie, by dokonywać oceny skrajnych możliwości rozwoju wypadków mogących pojawić się w przyszłości.

Damasio dowodzi, że markery somatyczne posiadają ściśle fizjologiczne podłoże. Część z nich ukształtowana została w procesie ewolucji, większość powstała $w$ naszym umyśle $w$ czasie procesu edukacji i socjalizacji poprzez łączenie określonych klas bodźców z klasami stanów somatycznych. A zatem markery somatyczne to $\mathrm{w}$ pewnym sensie efekt działania środowiska kulturowego. Na poziomie neuronowym powstawanie markerów somatycznych opiera się na procesie uczenia się systemów, które potrafią łączyć pewne kategorie bytów lub wydarzeń z przyjemnymi lub nieprzyjemnymi stanami ciała.

Damasio zauważa, że ewolucja jest oszczędna i woli łatać i dobudowywać niż tworzyć od nowa. Ukształtowała w mózgach licznych gatunków opierające się na ciele i zorientowane na przetrwanie mechanizmy decyzyjne. Mechanizmy te okazały się efektywne w różnych typach nisz ekologicznych. Najstarsze z perspektywy ewolucyjnej mechanizmy decyzyjne dotyczą regulacji biologicznej, następne odnoszą się do dziedziny osobistej i społecznej, najmłodsze zaś potrafią operować na zbiorach elementów abstrakcyjno-symbolicznych, czego przejawem jest twórczość artystyczna, rozumowanie naukowe, rozwój języka i matematyki (Damasio 1999, 217).

$\mathrm{Na}$ proces rozumowania składają się, zdaniem Damasio, trzy komponenty: zautomatyzowane stany somatyczne wraz z ich mechanizmami ukierunkowującymi, pamięć operacyjna oraz uwaga. Wszystkie te elementy współdziałają w wykonywaniu zadania, które polega na porządkowaniu równolegle pojawiających się reprezentacji. Problem polega na tym, że konstrukcja mózgu pozwala na świadome wytwarzanie tylko ograniczonego strumienia informacji mentalnej i ruchowej. Obrazy składające się na nasze myśli muszą być ustrukturyzowane we frazy, które $\mathrm{z}$ kolei muszą układać się $\mathrm{w}$ 
„struktury zdaniowe”. To samo odnosi się do ruchów stanowiących reakcje zewnętrzne, a mających przynieść oczekiwane przez nas rezultaty. Dobór ram, w których tworzone mają być owe frazy i zdania naszych myśli i ruchów, opiera się na równoległym przeglądzie możliwych opcji. A ponieważ zarówno myśl, jak i uwaga wymagaja przetwarzania współbieżnego, budowanie owych uporządkowanych sekwencji trwa nieprzerwanie. Przegląd możliwych opcji polega na określeniu ich kolejności. Określenie tej kolejności wymaga kryteriów jej ustalania (preferencji, wartości). Kryteriów tych dostarczają markery somatyczne (Damasio 1999, 226).

Wiele decyzji podejmowanych $w$ procesach rozumowań ma wpływ na przyszłość organizmu. Słuszne wydaje się zatem, zdaniem Damasio, że niektóre z owych kryteriów - pośrednio lub bezpośrednio - zakorzenione są w popędach biologicznych organizmu (które można uznać za jego 'rozumy'). Popędy biologiczne mogą być wyrażane jawnie lub skrycie $\mathrm{i}$ wykorzystywane jako markerowy system ukierunkowujący, uruchamiany przez skupienie uwagi na reprezentacjach utrzymywanych przez pamięć operacyjną w aktywnym stanie.

Człowiek nabył zautomatyzowany mechanizm markera somatycznego również dzięki tworzonej przez siebie kulturze i cywilizacji. Chociaż jego korzenie sięgają regulacji biologicznej, objął on również normy kulturowe, stworzone, by przetrwać w danej społeczności.

Działanie popędów biologicznych, stanów ciała i emocji jest, jak twierdzi Damasio, konieczną podstawą racjonalności. Owe niższe poziomy kierują bezpośrednimi, wzajemnymi powiązaniami pomiędzy mózgiem i ciałem właściwym, umieszczając ciało $\mathrm{w}$ łańcuchu operacji, który pozwala na osiagnięcie wyżyn intelektualnych i twórczych. Racjonalność, innymi słowy, jest kształtowana przez sygnały pochodzące $\mathrm{z}$ ciała. Damasio twierdzi wręcz, że organizm ma pewien rodzaj rozumu, który musi być wykorzystywany przez rozum. Weryfikacja słuszności dokonywanych wyborów za pomocą narzędzi logicznych jest procesem wtórnym, deszyfrującym reguły automatycznej preferencji (Damasio 1999, 229).

Damasio, opisując działanie umysłu, zakłada istnienie ścisłej współzależności procesów umysłowych i fizjologicznych. Procesy umysłowe cechuje wysoki stopień zautomatyzowania, a ów automatyzm ma swoje biologiczne podłoże. Taki sam automatyzm, zgodnie z przedstawioną hipotezą, 
dotyczy działania markerów somatycznych, które ukształtowane zostały na bazie doświadczenia kulturowego.

Recenzent książki Bląd Kartezjusza pisze, że wyrosła ona z przekonania autora, że tradycyjne poglądy na naturę umysłu nie mogą być słuszne - Damasio kwestionuje więc dualizm, wyjaśniając właściwe relacje między ciałem i umysłem, zarówno na gruncie biologii, jak i kultury.

Filozoficzny fundament teorii Damasio stanowi zatem spór $z$ kartezjańską odmianą racjonalizmu, spór prowadzący do jej odrzucenia. Jako alternatywę otrzymujemy teorię, którą można by nazwać teorią „wcielonego umysłu", zadziwiająco zbieżną z leibnizjańską wersją racjonalizmu, budowaną na negacji zasady dualizmu. Damasio nie odwołuje się jednak do systemu filozoficznego Leibniza, warto zatem wskazać te idee Leibniza, które stanowić mogą historyczno-filozoficzne zaplecze teorii Antonia Damasio.

Leibniz przedstawił idę̨ wszechświata jako harmonijnego systemu, w którym występuje zarazem jedność i różnorodność, koordynacja i podział części, a ten cudowny porządek wynika $\mathrm{z}$ faktu, że przyroda jest zegarem bożym. Wprawdzie u podstaw jego modelu przyrody legły prawa mechaniki, ale przyjmując ten punkt wyjścia - Leibniz podkreślał, że prawa te nie zależą od rozciagłości matematycznej, ale od pewnych przyczyn metafizycznych. Jego zdaniem, podstawowym brakiem fizyki mechanistycznej było nieuwzględnianie czynników dynamicznych istniejących $w$ przyrodzie. Zastępując kartezjańską zasadę zachowania ruchu zasadą istnienia doskonałej równowagi pomiędzy przyczyną a jej skutkiem, Leibniz wyprowadził z niej konsekwencje metafizyczne. Mianowicie, że siła, energia, choć mierzalna jej przyszłym skutkiem, jest czymś rzeczywistym, istniejącym stale w ciałach (Zob. Święczkowska, 1998, 17 i n.).

W języku leibnizjańskiej metafizyki pojęcie siły oznacza dążność czyli jeden z podstawowych atrybutów konstytuujących elementarną jednostkę bytu, zwaną przez Leibniza substancją, albo prawdziwym atomem natury. Drugi atrybut, to postrzeganie (percepcja), które jest zawsze pewną konsekwencją dążności.

Świat przyrody, którego budulcem są niepodzielne punkty metafizyczne - substancje, uporządkowany jest zgodnie z zasadami boskiego rachunku. Ma on wprawdzie u Leibniza zjawiskowy status, lecz jest to świat zjawisk dobrze ugruntowanych. 
Dążność i percepcja, rozważane na poziomie substancji pozostają w ścisłym związku ze światem fizycznym. Leibniz w wielu miejscach podkreśla, że „wszystkie duchy, wszystkie dusze, wszystkie substancje proste stworzone są zawsze w jakimś ciele i że nie ma żadnych dusz, które by były od niego całkowicie oddzielone" (Leibniz 1955 I, 20). Wprowadzone przezeń pojęcie substancji cielesnej oznacza dowolną istotę żywą. W liście do Arnaulda wyjaśnia to następująco: „Zakładając, ze w zwierzętach lub w innych substancjach cielesnych znajduje się dusza czy entelechia, trzeba by było w tym aspekcie rozumować tak, jak wszyscy rozumujemy w wypadku człowieka, który jest bytem obdarzonym przez swoją duszę prawdziwą jednością, mimo że masa jego ciała jest podzielona na organy, naczynia, płyny, tchnienia i że te części bez wątpienia pełne są nieskończenie wielu innych substancji cielesnych obdarzonych swymi własnymi entelechiami" (GP II, 120).

Leibniz, utrzymując, że każdej substancji przysługuje w ogólnym znaczeniu to, co nazywa dążnością i postrzeganiem, czyni ze zdolności poznawczych substancji podstawę ich klasyfikacji. Nazwę ogólną monad albo entelechii zachowuje dla substancji, które posiadaja aktywność poznawczą bliską minimum, a której początkiem jest, jak się wydaje, zdolność do samych tylko nieuświadomionych postrzeżeń. Te monady, u których postrzeganie połączone jest z pamięcią lub czuciem, nazywa Leibniz duszami, dusze zaś wyposażone w zdolność do postrzegania połączoną z pamięcią i świadomością zdolne do rozumowania, zwane są duszami racjonalnymi albo duchami (Święczkowska 1998, 24).

Każdy ogląd świata, każde postrzeżenie pozostaje w doskonałej zgodności z perspektywą posiadaną przez Boga, zaś prawdziwość „widoku boskiego" stanowi gwarancje prawdziwości postrzeżeń stworzonych przez Boga substancji.

Aktywność poznawcza wszelkich substancji podporządkowana jest boskiej zasadzie racji dostatecznej. Owa aktywność, niezależna $\mathrm{w}$ pewnym sensie od stopnia złożoności organizmu, odpowiada także boskiemu porządkowi wszechświata. Porządek ten jest zaś, zdaniem Leibniza, porządkiem matematycznym. Przypomnijmy raz jeszcze, że gdy Bóg rachuje i snuje myśli, świat się staje.

To metafizyczne założenie o algorytmiczności procesów poznawczych pojawia się współcześnie w kontekście teorii ewolucji. Niektórzy badacze 
(należy do nich m. in. Daniel Dennett) analizując teorię doboru naturalnego, twierdzą, że przetrwały tylko te gatunki, które wykształciły sprawnie funkcjonujące wysoko wyspecjalizowane mechanizmy poznawcze i zachowuja się tak, jakby rozpoznały „swobodnie unoszącą się dla nich rację”. Przytaczając podobne poglądy Roger Penrose, pisze: „Jeśli zakładamy, że zarówno świadome, jak i nieświadome działania ludzkiego mózgu polegają wyłącznie na wykonywaniu pewnego bardzo skomplikowanego algorytmu, to musimy zadać sobie pytanie, w jaki sposób powstał taki nadzwyczaj skuteczny algorytm. Standardowa odpowiedź brzmi: „W miarę postępu ewolucji, jednostki posiadające bardziej skuteczne algorytmy miały większe szanse przeżycia, a zatem liczniejszego potomstwa. Ponieważ potomstwo to dziedziczyło po rodzicach fragmenty lepszych algorytmów, na ogół posiadało przewagę nad swoimi gorzej wyposażonymi kuzynami. W ten sposób algorytmy działania były stale ulepszane, choć oczywiście proces ten nie przebiegał bez zakłóceń" (Penrose 1995, 454).

Powstaje pytanie, czy owe procesy poznawcze, właściwe wszelkim organizmom na różnych poziomach ich złożoności można odtworzyć, posługując się narzędziami wypracowanymi przez twórczy rozum. Inaczej mówiąc, jeśli działanie organizmów przebiega według pewnego racjonalnego planu, możliwa jest jego symulacja. Damasio mówi o automatyzacji procesów decyzyjnych, mających zasadniczy wpływ na przyszłość organizmu, możliwej dzięki mechanizmowi markera somatycznego. Twierdzi, że reguły logiczne, reguły czystego rozumu moga stanowić jedynie uzupełnienie owego mechanizmu, ale nie one w istocie rozstrzygają o efektywności rozumowań.

Powróćmy do wątku Leibniza. Dusze racjonalne, czy też jednoczące agregaty monad umysły zdolne sa, jego zdaniem, do rozpoznania i odtworzenia matematycznego planu stwórcy. Ów plan, ujęty w naturalny porządek idei, jest zresztą wpisany w umysł każdego człowieka. Leibniz założył, że apercepcja, czyli myślenie prowadzące do idei, ma charakter algorytmiczny. Naturalny porządek idei jest izomorficzny z porządkiem wszechświata, porządek ten zaś jest konsekwencją działań Stwórcy, który wybierając najlepszy z możliwych światów, stworzył go zgodnie $\mathrm{z}$ wewnętrznym porządkiem własnych myśli. Ufając sile twórczego umysłu, Leibniz wierzył, że człowiek jest w stanie odtworzyć ten naturalny porządek idei i rozpoznać złożoność wszechświata na wszystkich jego poziomach. $\mathrm{Z}$ drugiej jednak strony istnieją zasadnicze 
problemy $\mathrm{z}$ pogodzeniem leibnizjańskiej wiary $\mathrm{w}$ cudowną moc algorytmu i dynamicznej struktury poznania wyłożonej w Monadologii, gdzie pisał: „Należy wszakże przyznać, że postrzeżenie i to co do niego należy, nie da się wytłumaczyć racjami mechanicznymi, to znaczy przez kształty i ruchy". Bowiem „żadna machina stworzona sztuką człowieka nie jest machiną odpowiadającą machinie boskiej, czyli naturalnemu automatowi" (Leibniz 1969, $300)$.

Można zatem powtórzyć za Damasio, że organizm ma pewien rodzaj rozumu, który musi być wykorzystywany przez rozum. Na ten pierwszy składać się może rozumność monad tworzących poszczególne części składowe organizmu, które zintegrowane są z monadą jednoczącą całe ciało - umysłem, duszą czy entelechią.

Zadziwiające podobieństwo do tej idei odnajdujemy w książce Daniela Dennetta Natura umyslów: „Nie tylko, że pochodzisz od ...makromolekularnych robotów, ale się z nich składasz, twoje cząsteczki hemoglobiny, przeciwciała, komórki nerwowe, twoja maszyneria działań odruchowych..., twoje ciało (łącznie z mózgiem, oczywiście) składa się z mechanizmów, które tępo wykonują wspaniała, perfekcyjnie zaprojektowaną robotę..., składamy się $\mathrm{z}$ robotów - lub, co oznacza to samo, jesteśmy zbiorem trylionów makromolekularnych mechanizmów... coś, co składa się z robotów, może przejawiać autentyczną świadomość...”(Dennett 1997, 36)

Dopowiedzieć wszakże należy, pod warunkiem, że są to roboty naturalne, czyli boska maszyneria.

$\mathrm{Na}$ postawione $\mathrm{w}$ tytule pytanie można udzielić przynajmniej częściowej odpowiedzi. Wielu badaczy podziela przekonanie, że znaczna część procesów poznawczych i podejmowanych $w$ ich wyniku działań, przebiega $w$ organizmie automatycznie. Jest ono akceptowane $w$ zasadzie $w$ odniesieniu do organizmów niższych. Problem dotyczy jednak w istocie tych procesów poznawczych, które rozstrzygają o różnicy gatunkowej między człowiekiem i światem zwierząt. Tu sprawa jest otwarta. 


\section{BIBLIOGRAFIA}

1. Antonio R. Damasio, Bład Kartezjusza, Poznań 1999.

2. Daniel C. Dennett, Natura umyslów, Warszawa 1997.

3. Gottfried W. Leibniz, Nowe rozważania dotyczace rozumu ludzkiego, t. I, II, PWN, Warszawa 1955.

4. Gottfried Wilhelm Leibniz, Wyznanie wiary filozofa, PWN, Warszawa 1969.

5. GP - Die Philosophischen Schriften von G. W. Leibniz, VII Vol. ed. C. I. Gerhardt, Halle 1846-1863 (repr. Hildesheim 1960), cytowane jako tom, strona.

6. Roger Penrose, Nowy umyst cesarza, PWN, Warszawa 1995.

7. Halina Święczkowska, Harmonia linguarum. Jezzy i jego funkcje w filozofii Leibniza, Wydawnictwo Uniwersytetu w Białymstoku, Białystok 1998. 